\title{
The Use of Digester and the Spread of Sustainable Actions in Semiarid Region of Ceará
}

\author{
José Falcão Sobrinho ${ }^{1}$, Vanessa Campos Alves ${ }^{2}$, Thaylany Matias Magalhães ${ }^{2}$, Gilmário Rodrigues do \\ Nascimento $^{2}$ \& Emanuela Lima Lutif Pinto ${ }^{2}$ \\ ${ }^{1}$ Associate professor in the geography master's course for the Universidade Estadual Vale do Acaraú (UVA), \\ Sobral, Ceará, Brazil \\ ${ }^{2}$ Researcher for the laboratory of researches and extension of the semiarid region, UVA, Sobral, Ceará, Brazil \\ Correspondence: José Falcão Sobrinho, Associate professor in the geography master's course for the \\ Universidade Estadual Vale do Acaraú (UVA), Sobral, Ceará, Brazil. E-mail: falcao.sobral@gmail.com
}

Received: May 20, 2020 Accepted: August 8, 2020 Online Published: August 19, 2020

doi:10.5539/jms.v10n2p15 URL: https://doi.org/10.5539/jms.v10n2p15

\begin{abstract}
The objective of this manuscript is to present comments about the social technology involving the production of renewable energy using the digesters implemented by the Paulo Freire project in some country estates in Massapê and Jordão. For this, visits were necessary for these two municipalities, where it is possible to realize the importance of these digesters for the local people. Furthermore, some aspects affect the production in the field, such as the interaction among types of social technology and the importance of available natural resources for obtaining results that impact positively on the local economy and sustainable rural development. The diffusion of rural and environmentally sustainable development actions goes through the guarantee of resources for the development and autonomy of the population.
\end{abstract}

Keywords: digester, rural development, social technology

\section{Introduction}

The landscapes approached through the history of semiarid sertões have always revealed a significant influence of a hot climate that submits nature and human life to an aggravating shortage of natural resources. The real character of sertões started presenting its first change traces with the collaboration of public policies and third sector organizations, which made possible the implementation of technology to support life in the semiarid region. The focus of this technology is on ways of obtaining water for families, raising animals, growing crops, managing land and producing renewable energy for the most varied use.

Public policies have recently allocated significant resources to the semiarid region, aiming to promote rural development more sustainably and improve the farmers and their families' lives (Küster \& Martí, 2009, p. 13). Besides being sustainable, technology must be affordable and easily adaptable to both social and spatial contexts to be useful and assimilated to the local reality. Thus, the drought effects would be softer during the dry season and, not only the quality of life would be better but also the autonomy and livelihood of local families.

Sustainability, according to Cabestré, Graziade and Polesel (2008), is the relationship between the economic and ecologic systems in which human life would continue indefinitely and whose effects would have limits without destroying the diversity, complexity and functions of the ecological life support system. The objective here is to present comments regarding the digester, which is a form of reducing environmental pollution and producing biogas and biofertilizer. The devices were set in some country estates in the municipalities of Massapê/CE, in Trapiá, and Jordão, in Serra do Rosário, establishing a relationship between their local context and function. The implementation of digesters in that area proved to be significant and feasible.

\section{Discussion}

The studied areas were a rural community called Trapiá, in Massapê, and the Serra do Rosário, which is a district of Jordão that belongs to Sobral. The responsible for this project was the Paulo Freire project, which organizes actions to fight against poverty in rural communities to improve the standard of living of farmers and families who have a low Human Development Index (HDI) (Figure 1). The project receives financial support from the Government of Ceará and the International Fund for Agricultural Development (IFAD). 


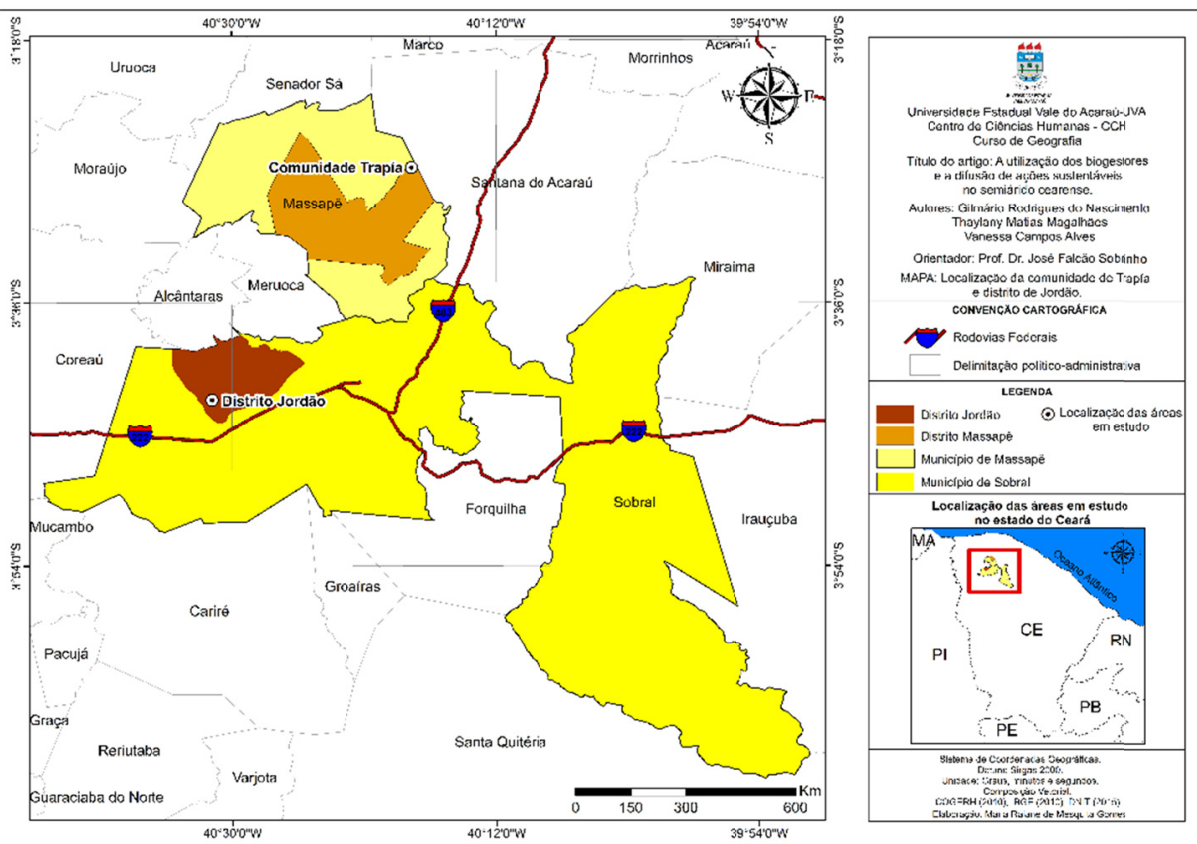

Figure 1. Location map (GOMES, 2019)

Massapê (11km far from Trapiá) and Sobral (16km far from Jordão) are cities surrounded by the Sertaneja depression, which is characteristic of the semiarid landscape along with a slightly wavy and lowered relief due to erosion and weathering. Altitudes of up to $400 \mathrm{~m}$, lithological diversity, shallow soil, rocky outcrop, different degradation levels and caatinga vegetation are typical in this region (Souza, 2006). Trapiá is in the Sertaneja depression to the South of Meruoca, whereas Jordão, in Serra do Rosário, is leeward, or dry hillside, due to windward orographic obstacles to the North (Evangelista \& Lima, 2007). Thus, characteristics similar to those of the depression stand out on the leeward slopes. It comprises the humid residual massifs, which are described by Souza (1979) as a relief resulting from the erosional processes that occurred in the Cenozoic Era. Thus, the pediplain in that region became what is now the Sertaneja depression because of significant modifications.

The prevailing climate is semiarid, whose temperatures vary and become milder and humid in the mountains with a significant soil profile. An example area in the Sertaneja surface is Serra da Meruoca, which is in the SW-NE direction with elevations of up to $920 \mathrm{~m}$ and slopes between $700-800 \mathrm{~m}$ in comparison with the surrounding pediplain (Lima, 1999). It presents edaphoclimatic conditions that favor the vivid agricultural use of different crops. The dry mountains, ridges and groups of inselbergs have similar conditions to those in mountainous depression (Souza, 2006).

Given these characteristics and influences that the semiarid climate exerts on places, the consequence was the creation of lifestyles and adaption methods to such an environment. For many decades, development projects for the Brazilian semiarid region were out-of-context practices and focused on great works to fight against drought (Gualdani, Fernandez, \& Guillén, 2015). After this moment, a new look at the reality of the sertões sought to exchange knowledge and experiences with local families to conceive social technology capable of promoting social, economic and environmental development. It would occur through actions to preserve the natural resources available in the environment by adapting them to the spatial context of each production unit.

According to Araújo Filho (2006), the exploitation of natural resources is the principal source of subsistence of the local population in the caatinga semiarid region, which contributes to the degradation of these resources. As a form of spreading sustainable actions and ecological adaptation methods, the Paulo Freire project took rural not only provided technology but also offered technical support to the families through the spread of practical knowledge necessary for better development of projects. This project lies on the responsibility of the Centro de Estudos do Trabalho e Assessoria ao Trabalhador (Centre for Labour Studies and Worker Advice, CETRA).

\section{Material and Methods}

This research discusses how the adoption of technology to assist life in the semiarid environment has contributed 
to a new way for people to deal with the place where they live, considering the relationship among them, the productive system and the environment. Some aspects in this context influence the productivity in the field, for example, the interaction between the used technology and the natural resources available. This availability is essential to impact positively on the local economy and sustainable rural development.

The following steps were essential for the development of this paper:

The first step, which fostered an embedded study of the systems nature and the relationship among themselves, considered the need to assign as methodological support the general systems theory proposed by Ludwig von Bertalanffy in 1930 due to its integrative perspective of the various fields of knowledge. The use of this theory in this research tries to understand not only the harmonic and balanced relationship between society and nature but also highlights its importance for the economic development of rural workers and the quality of life from sustainable practices. The acquirement of further knowledge of digesters occurred through the consultation of online materials in the online collection of the Empresa Brasileira de Pesquisa Agropecuária (Brazilian Agricultural Research Corporation, EMBRAPA), literature reviews from (Barichello et al., 2011; Silva, 2019) and other references.

The second step was indoor, where all the literary knowledge gathered in the previous stage was systematized to prepare the researches for the fieldwork.

The fieldwork, third step, in both areas, took place between August 2019 and February 2020. Three visits occurred in each one, where employees from the Union of Agricultural Workers, representatives of rural communities and professors provided technical support.

The first visit served to know the space, acquiring environmental and daily information from meetings scheduled with representatives and family members of each area. These moments were essential to obtain the coordinates of the place for use in the location map illustrated in Figure 1 and to collect information to compose the comparative Table 1.

During the second visit, researchers and professors obtained better knowledge by addressing issues related to the understanding the technology, such as the model, components, the transformations after implementation, the difficulties faced by farmers in the maintenance and performance of this system, their way of dealing with the available natural resources, the productivity generated and its economic directions. The use of photographs helped to illustrate the work of data from each location. The third visit was a return to the rural communities to have answers for some questions and to thank the involved people for the collaboration.

\section{The general systems theory as an integrative perspective between humans and the environment in landscapes}

The development of the general systems theory occurred initially through its application to thermodynamics and biology in the studies of the Hungarian biologist Ludwing von Bertalanffy. In time, it has contributed to an advancement in the study of nature, especially in the field of geographic science. Francisco Mendonça (1991) explains that Tansley (1937), using this method in ecology, created the concept of ecosystems, which later influenced geomorphology (Chorlley, 1994) and physical geography (Sotchava, 1962; Bertrand, 1968; Tricart, 1977) in general.

The concept of systems, according to Bertalanffy (1977, p. 63), consists of a set of interacting elements. As for Tricart (1977), he states that flows of matter and energy process systems, giving birth to mutually dependent relationships among the phenomena, to which he attributed subsystems to each.

From the general systems theory, Viktor Sotchava created the geosystemic theory as a specific method for geographic studies. The systemic view in the concept of geosystem, when applied to the study of landscape, finds the ideal approach for its applicability. Geosystems is geographic analyses from the combination of natural (climate, geology, geomorphology, hydrology, pedology) and social elements expressed through biologic exploration (human action). This combination, in turn, gives the landscape a dynamic character in time and space From the 1970s on, the geosystemic theory became important in environmental studies due to Georges Bertrand's studies.

\section{Result and Discussion}

Currently, the principles of preservation and sustainability generate a new challenge for farmers by inserting new forms of social organization and management of natural resources available in the environment. The development of techniques employed in this new reality is an agent of the transformation of natural landscapes with the insertion of cultural elements. An example highlighted in this manuscript is the rural space delimited for 
this research. In these spaces, there is a productive system composed of a set of social technology adapted to the environmental context and the lifestyle of the community.

One of the components of this system is the digester. It consists of a device where the fermentation of biomass by bacteria that decompose the organic matter anaerobically takes place (Barichello, 2011). The outcome is the production of methane, which is a source of energy and biofertilizer to be used in agriculture. Thus, this is a sustainable alternative capable of promoting the reduction of the progressive extraction of firewood and the adequate treatment of animal excrements, which is responsible for the soil and water pollution. Therefore, it not only improves the sanitary conditions of the environment and eliminates the proliferation of parasites that cause diseases but also assists the economy of families by using biogas at zero cost. Figure 2 shows the technology used for this purpose, as well as its main components.

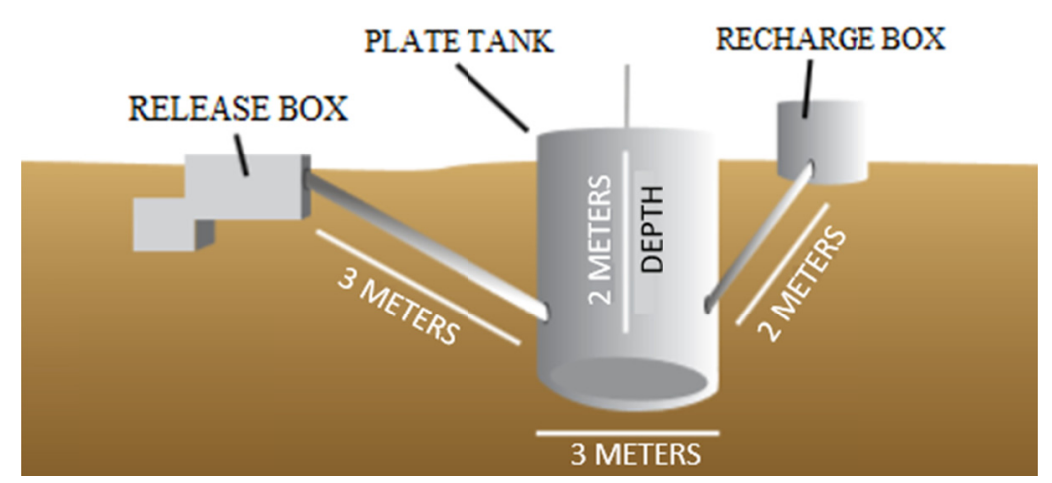

Figure 2. The digester componentes (Convivência com o Semiárido Brasileiro: Reaplicando Saberes através de Tecnologias Sociais, 2015)

This device is composed of three components:

Recharge box. It is a $70 \mathrm{~cm} \times 60 \mathrm{~cm}$ concrete ring where cattle, poultry, pigs and goats excrement are dumped and diluted in water. Due to gravity, the manure goes from the recharge box to the fermentation tank through the PVC pipe.

Plate tank. It is where the fermentation of organic matter occurs to produce biogas. Ring-shaped concrete plates make up the base of the $2 \mathrm{~m}$-depth tank. Above the fermentation tank, there is a $1000 \mathrm{~L}$ hanging water tank to store biogas. It is also important to highlight some relevant components in this digester model for the safety of the users. The sustenance support is responsible for keeping the water tank in place, making it impossible for the biogas to leak. The gas filter is a $20 \mathrm{~L}$ bottle filled with 5 liters of water. The biogas produced in the fermentation process goes inside the gas filter and undergo the filtering process to have all impurity removed.

Release box. It is where the biofertilizer, used for garden fertilization and the organic fertilizer to keep the soil fertile, can be removed.

From observations carried out in the fieldwork, the result is that the most common model implemented in both locations is the Indian model, as shown in Figure 2, whose construction material undergoes adaptations according to the availability of the institution. The average cost for the construction and technical training for the families is R \$ 4,000.00. The following Figures 3 and 4 show the digester set in Trapiá and Jordão. 


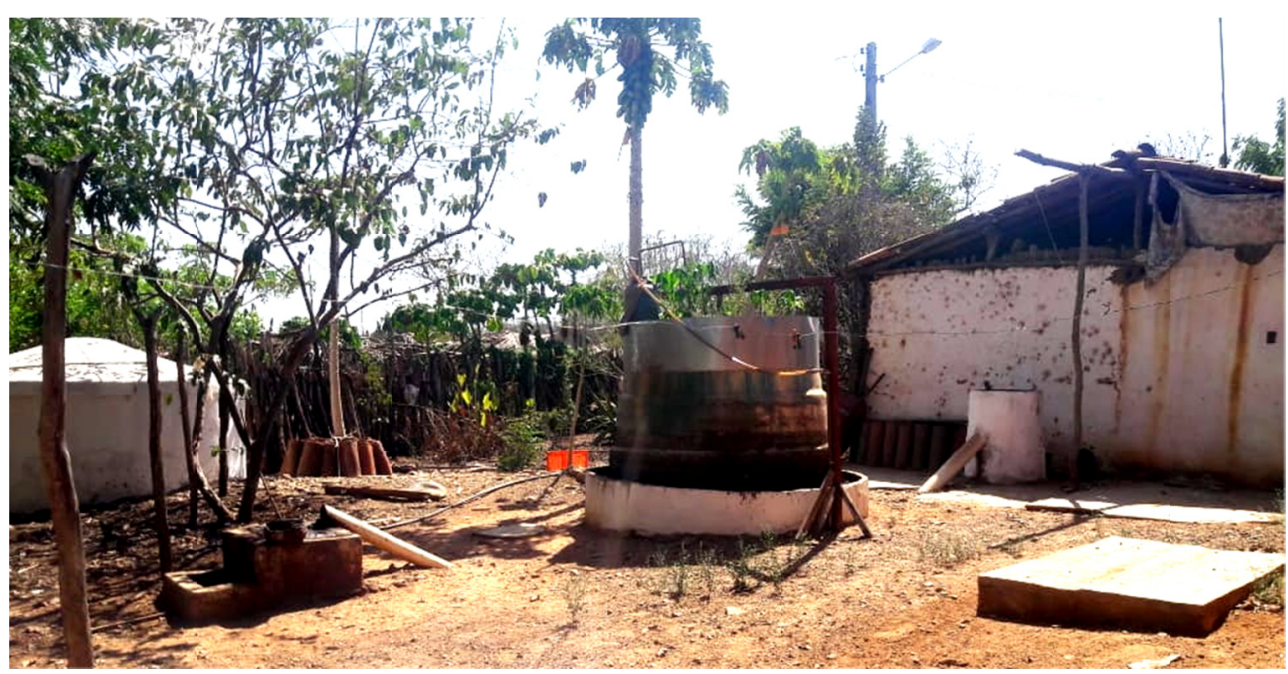

Figure 3. The digester in Trapiá (own photo)

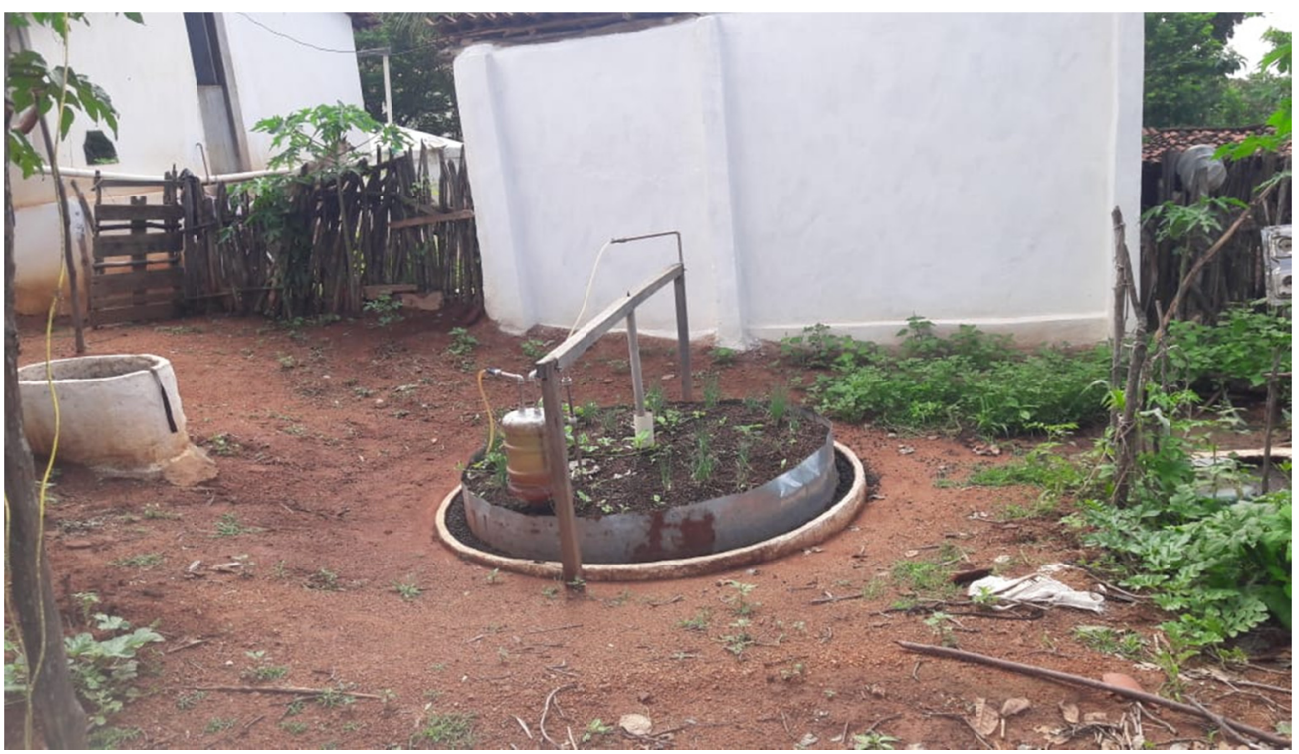

Figure 4. The digester in Jordão (own photo)

Manure is essential for digesters since the supply is the result of this material diluted in water, turning it into a pasty mixture that makes the revolving easy for fermentation. According to the owners, it is necessary to use two $20 \mathrm{~L}$ manure buckets to each water bucket with a continuous supply, taking into account the daily gas consumption. They also say that it is necessary to take care that the manure does not get dried and stick on the walls of the tank since it stops the digester from producing biogas. This way, regular maintenance, at least once or twice a week, must be carried out by moving the gas chamber and removing solidified manure from the walls.

In the visited properties, there are five types of technology structured to work in a full-time scheme, namely the digester, the water reuse, the earthworm farm, a cistern for agriculture and another for domestic use. By using a digester, the owner no longer needs to spend money on cooking gas, which according to the householders they used to spend about two gas cylinders per month for $\mathrm{R} \$ 70.00$ each. After the implementation of digesters, the need for cooking gas is being supplied, thus, generating savings in family income of $\mathrm{R} \$ 1680.00$ per year. Besides allowing the owner to obtain the administration and use of supplies such as animal manure, biogas, biofertilizer and organic fertilizer, this fertilizer also has the benefits of the function of natural agricultural defensive and food for the earthworm farm.

Water reuse and cisterns, which promote high-quality water for home and agricultural use, has the function of 
reusing greywater from bathrooms and sinks. First, the greywater goes to installments intended for filtering impurity through the fat box, then to the earthworm farm that serves as a biological filter and finally goes to a well. The earthworm farm, which integrates the digester and the water reuse, generates income for the owner who sells hummus and worms. The digester provides the energy and fertilizer produced as food for the earthworm farm, having as final product the hummus used for seedling germination.

Finally, the crops produced by the families are for their consumption and sale at the agro-ecological market organized and held every two weeks in the business district of Sobral, Massapê and in the community itself, resulting in profits. It is worth noting that the technology present in Jordão and Trapiá complement each other in their uses, which helps to produce and sustain rural properties. The living environment of farmers amounts to the entry of matter that goes through the system. The output serves as a source of income and as the material used to the health of the system. Summarized and compared information of the elements observed in the fieldwork are in the table below.

Table 1. Comparison between aspects of the two studied areas.

\begin{tabular}{lll}
\hline & MASSAPÊ & JORDÃO \\
\hline GEOMORPHOLOGIC UNIT & Sertaneja depression & Residual massif \\
AGRICULTURAL CROP & Mango, papaya and grass & Onion, cilantro, parsley and cashew \\
FARMING & Cattle, pig and sheep & Goat \\
MANURE & Cattle & Goat \\
WATER RESOURCE & Cistern, watercourse and well & Cistern and well \\
\hline
\end{tabular}

Note. Own table.

The climatic variations, geological structure, relief, soils and vegetation are variables that define the characteristics of the natural systems formed by the dynamics of the ground and condition the different forms of uses and occupations in each environment.

According to Ab'Saber (1974), the regional climate system involves a significant input of solar energy, alongside relatively scarce and very irregular rainfall. The high solar incidence rates, along with the low impermeability of the crystalline soil, allow for the formation of rivers and streams with intermittent and seasonal drainage. In this context, the vegetation cover helps to retain soil moisture and its conservation by controlling erosion and leaching.

In Massapê and Jordão, the semiarid climate prevails and coexists with the social systems that act in the face of its potentialities and limitations. At the local level specified for this research, there is the integration of three aspects that constitute the productive systems, namely the available natural resources, the economy and the local sustainability. These resources, which are are fauna, flora, soils, water, solar energy, mineral resources and others, are natural and useful to humans because they contain social, economic and cultural values.

According to Grissi (2007, p. 201), natural resources are renewable or non-renewable. Renewable resources are those resources that can be renewed by natural processes when used at a lower speed than their replacement capacity. Non-renewable resources, whose natural replacement occurs quite slowly, have limited availability in the earth's crust.

It is worth noting that the economic values of these resources are visible through the relationship of coexistence with the semiarid region through the insertion of social technology established in this context as a productive social system. Based on Mazoyer's definition; Roudart (1998), when they consider that

The productive social system (technical, economic and social) is composed of men and women (labor force, knowledge and know-how), tools (productive instruments and equipment) and living matter (crops and animals) that provide the agricultural population with the means to renew and exploit the fertility of the ecosystem. With this, they meet directly (through self-consumption) or indirectly (through exchanges) their own needs (Mazoyer \& Roudart, 2010, p. 73).

Therefore, the sustainable management of these resources is essential to make them available for the balance of ecosystems and the development of human life. Through them, there are forms of establishing the economy through the work of the farmers, which ensures the working of the system and generates positive results.

The production in these spaces suffers influence according to the physical characteristics of the environment and its limitations. The analyzed areas are geographically in regions with water shortage, which is essential for the production of agricultural and livestock culture. To better understand this, it was necessary to evaluate the 
rainfall level figure in the two locations studied.

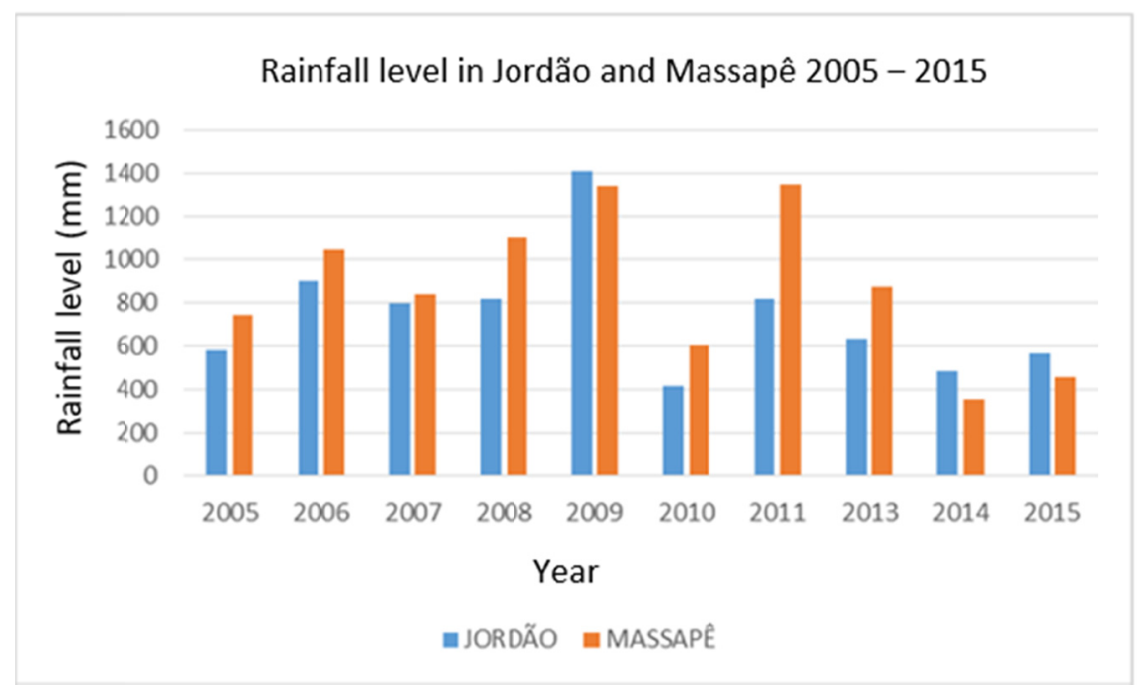

Figure 5. Rainfall level per year (FUNCEME)

Figure 5, which considers the rainfall level data from both areas over ten years, reveals high rainfall levels in Massapê because its location receives the orographic rain from Serra da Meruoca. However, it presents low levels in 2009, 2014 and 2015 when compared to Jordão. The data corresponding to the period of low rainfall level in Massapê does not interfere with the discussion made because although Jordão indicates periods of high rainfall level, there is a more significant and better distribution of rain throughout the year in Massapê.

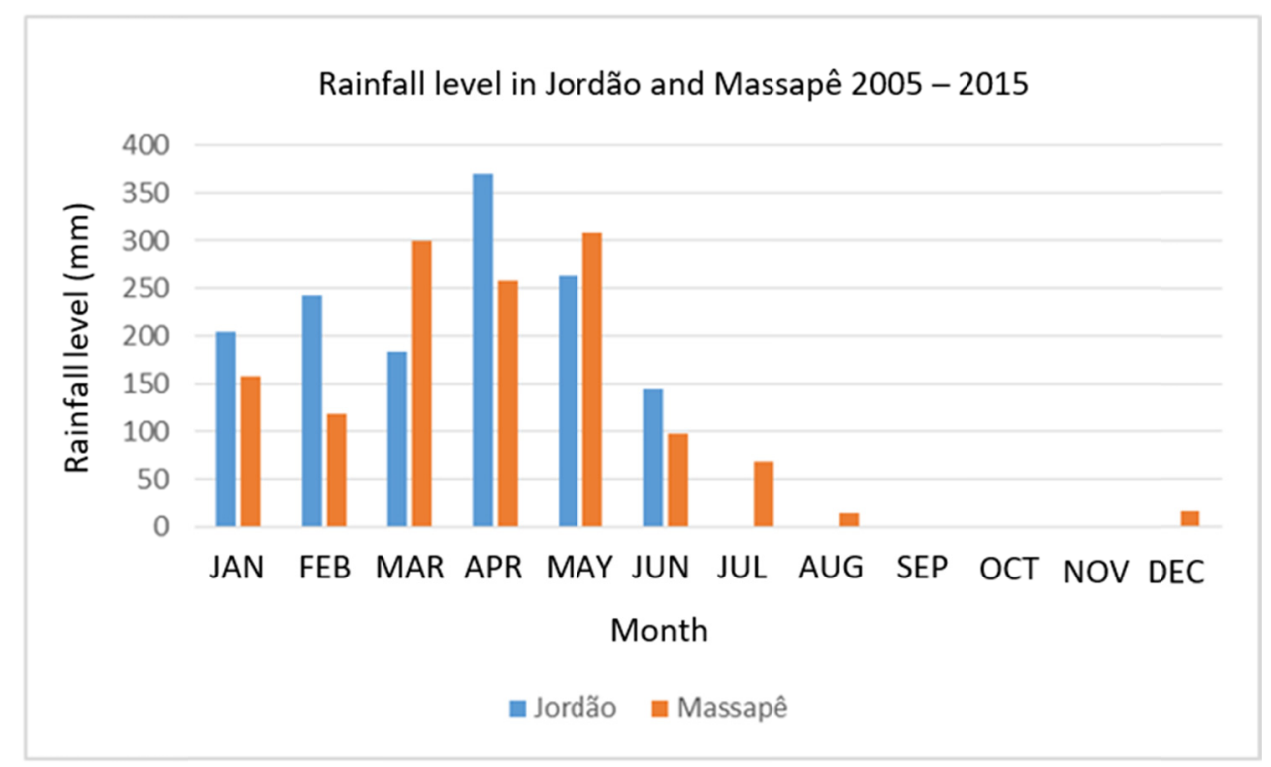

Figure 6. Rainfall level per year (FUNCEME)

In Figure 6, it is possible to see that the distribution of rain is highly concentrated from January to June in Jordão and from December to August in Massapê, reducing the period of drought. According to IPECE (2017), the average rainfall level is $749.5 \mathrm{~mm} /$ year and, the average temperature ranges between $26^{\circ} \mathrm{C}$ and $28^{\circ} \mathrm{C}$ in Massapê. Trapiá receives benefits from the effects of the windward side of Serra da Meruoca, providing diversity to agriculture and having rivers and streams that are born and run in the course of the depression. They use types of 
technology, such as cisterns and wells, to store water during the dry season due to the intermittence of the rivers. Access to water resources makes it possible to develop diversified agriculture and livestock, as shown in the table above.

According to data from IPECE (2017), Jordão, along with the municipality of Sobral, has an average rainfall level of $821.6 \mathrm{~mm} /$ year and average temperatures varying from $26^{\circ} \mathrm{C}$ to $28^{\circ} \mathrm{C}$. The natural characteristics of Serra da Meruoca provided influences from the leeward side of the massif in Jordão, presenting water shortage resources and poor spatial distribution of water. Considering the importance of interaction between animals and the environment, raising goats is due to the difficulties or disadvantages of raising other kinds of animals.

According to the Instituto Regional da Pequena Agropecuária Apropriada (Regional Institute of Appropriate Small Agriculture, IRPAA), raising goats is more advantageous to the rural population since these productive animals are more adaptive to the dry weather and not so costly to keep. For example, a cow consumes $53 \mathrm{~L}$ of water a day, feeds the equivalent of what eight goats consume, conceives one calf each year and produces about three liters of milk. On the other hand, eight goats consume about $48 \mathrm{~L}$ of water a day, eat the same as one cow, conceive twenty goat kids every year and produce $4 \mathrm{~L}$ of digestive milk richer in nutrients, which is three times more expensive than the cow's one. Besides, goats hang around easily in different types of ground and can access several areas in search of food when they are loose in pasture areas, and thus obtain access to greater food diversity. Since the crops suffer restrictions due to water shortage in the area, the population needs cisterns and wells to meet their needs.

\section{Final Consideration}

The Brazilian semiarid region has presented itself throughout its history as a definable place to different perspectives and views. When analyzing its historical transformation, it is interesting how the image of a dry and underdeveloped environment with a fragile ecosystem has turned into a place of possibilities. Besides, the ecosystem has proved itself resistant and adaptable to the severe climatic conditions. Malvezzi once said (2007, p. 9) that the Brazilian semiarid region is not only climate, vegetation, soil, sun and water but also people, music, celebration, art, religion, politics and history. It is a social process that can not be understood from one angle only. Therefore, the problem of the sertão is not only restricted to natural physical conditions but also lies in human and political action on the environment with technology and investments aimed at environmental preservation. With the rational use of natural resources, there is a chance for the valorization and multiplication of sustainable actions. Social technology of coexistence with the semiarid territory promotes means for families to adapt to the climate of the region and its effects on the environment, ensuring the permanence and the valorization of productive units. To get positive results from the discussed technology, they must undergo adaptations based on the context in which families live and consider their local knowledge and experiences.

According to Falcão Sobrinho (2007), human action has to do with the dimension humans have for the place and the way of dealing with the earth, having support on it. Therefore, education in schools, as one of the fundamental pillars in the social construction of individuals, must involve more and more students to know about the place where they live and act with more awareness from the experiences and knowledge acquired. Because of the natural capacities of the environment in which they live, there are possibilities to spread and integrate technologic devices of different functions more than as a result there is the possibility of family autonomy through local development and improvement of new knowledge in the field.

It is worth pointing out that the problem of sertão is not restricted only to natural physical conditions but also lies in human and political action on the environment. With technology and investments aimed at the development of agricultural and livestock activities along with the principle of environmental preservation with the rational use of natural resources and alternative forms, such as the sustainable production of biogas as a means of supplying energy, there is a chance for the valorization and multiplication of sustainable actions.

\section{Acknowledgment}

Thanks to the Union of Agricultural Workers and other rural workers from Massapê, to Mr. Cosmo and Mr. Assis from Jordão, to the technician Luciana and the owner of the area Mr. Valmir for their contribution and also to CNPq.

\section{References}

Barichello, R., Casarotto, F. N., Hofmann, R., Brondani, C., \& Bernardi, F. (2011). O uso de biodigestores em pequenas e médias propriedades rurais com ênfase na agregação de valor: um estudo de caso na região noroeste do Rio Grande do Sul. Em: ENEGEP 2011, 2011, Belo horizonte. Anais do ENEGEP 2011. Rio: Abepro, 1, 1-10. 
Cabestre, S. A., Graziade, T. M., \& Polesel, F. P. (2008). Comunicação Estratégica, Sustentabilidade e Responsabilidade socioambiental - um estudo destacando os aspectos teórico-conceituais e práticos. Anais XXXI Congresso Brasileiro de Ciências da Comunicação - Intercom: Natal/RN.

Evangelista, F. S., \& Lima, E. C. (2007). Análise geoambiental do vale do riacho Boqueirão - Sobral/CE. Revista Homem, Espaço e Tempo.

Falcao, S. J. (2007). Relevo e Paisagem: proposta metodológica (p. 108). Sobral: Sobral Gráfica.

Fundacao, C. d., \& Metodologia, e. R. H. (2020). Gráfico de Chuvas dos Postos Pluviométricos. Retrieved February 24, 2020, from http://www.funceme.br/?page_id=2702

Gualdani, C., Fernandez, L., \& Guillen, M. L. (2015). Convivência com o semiárido brasileiro: reaplicando saberes através de tecnologias sociais. Instituto Brasileiro de Desenvolvimento e Sustentabilidade - IABS/ Editora IABS, Brasília-DF, Brasil.

IPECE. (2017). Instituto de Pesquisa e Estratégia Econômica do Ceará. Fortaleza. Retrieved 2019, from https://www.ipece.ce.gov.br/wp-content/uploads/sites/45/2018/09/Massape_2017.pdf

IRPAA. (2020). Instituto Regional da Pequena Agropecuária Apropriada. Cabras e ovelhas: A criação do sertão. $4^{\circ}$ Edição revista e ampliada Juazeiro, outubro de 2001. Retrieved February 25, 2020, from https://irpaa.org/publicacoes/cartilhas/criacao-de-cabras.pdf

Kuster, A., \& Marti, J. F. (2009). Políticas públicas para o semiárido: experiências e conquistas no nordeste do Brasil. Fortaleza: Fundação Konrad Adenauer.

Lima, E. C. (1999). A serra da Meruoca. Revista da casa da geografia de Sobral, ano 1, n.1. Retrieved 2019, from http://rcgs.uvanet.br/index.php/RCGS/article/view/39

Malvezzi, R. (2007). Semi-árido uma visão holística. Brasília: Confea.

Silva, H. W. (2013). A tecnologia da biodigestão anaeróbica na produção de biogás gerado por dejetos de suínos. Revista Brasileira de Agropecuária Sustentável (RBAS), 3, 56-60. Retrieved from http://www.rbas.com.br/pdf/revista_5_artigo_114.pdf

Vale, C. C. (2012). Teoria Geral do Sistema: histórico e correlações com a Geografia e com o estudo da paisagem. ENTRE-LUGAR, 3(6), 85-108. Retrieved February 27, 2020, from http://ojs.ufgd.edu.br/index.php/entre-lugar/article/view/2448/1399

\section{Copyrights}

Copyright for this article is retained by the author, with first publication rights granted to the journal.

This is an open-access article distributed under the terms and conditions of the Creative Commons Attribution license (http://creativecommons.org/licenses/by/4.0/). 